\title{
BIOAEROSOLS IN THE SUBURBS OF OSTRAVA DURING A ONE YEAR PERIOD
}

\author{
Vítězslav Jiřík ${ }^{1}$, Ondřej Machaczka ${ }^{2}$, Veronika Ovesná ${ }^{1}$, Hana Miturováa ${ }^{3}$ Eva Holendováa ${ }^{3}$ Jana Janoutová1 ${ }^{1,2}$, \\ Vladimír Janout ${ }^{1,2}$ \\ ${ }^{1}$ Department of Epidemiology and Public Health, Faculty of Medicine, University of Ostrava, Ostrava, Czech Republic \\ ${ }^{2}$ Centre of Epidemiological Research, Faculty of Medicine, University of Ostrava, Ostrava, Czech Republic \\ ${ }^{3}$ Institute of Public Health in Ostrava, Ostrava, Czech Republic
}

\begin{abstract}
SUMMARY
Aim: The aim of this paper is to provide information about the concentrations of airborne bioaerosols (airborne bacteria, fungi and endotoxins) in outdoor suburban environments in Ostrava, Moravian-Silesian region, Czech Republic.

Methods: The methods were based on systematic bioaerosol monitoring during one calendar year, subsequent analysis of the samples and statistical processing. The regression, correlation analysis and analysis of variance for one factor and pairwise comparisons were performed on bioaerosol data to determine their dependence on season, daytime, temperature, humidity and dew point.

Results: The results show higher fungi concentrations especially in summer (corrected mean 365 colony forming units - CFU per $\mathrm{m}^{3}$ ) compared to other seasons $\left(75-209 \mathrm{CFU} / \mathrm{m}^{3}\right)$ and higher concentrations of bacteria in the evening $\left(380 \mathrm{CFU} / \mathrm{m}^{3}\right)$ compared to other parts of the day and seasons (in summer 206-252 CFU/ $\mathrm{m}^{3}$ and in winter $81-87 \mathrm{CFU} / \mathrm{m}^{3}$ ). Concentrations of endotoxins were relatively low throughout the year, on average 0,056 endotoxin units (EU) per $\mathrm{m}^{3}$.

Conclusions: The concentration of bioaerosol (bacteria, fungi and endotoxins) were found in ambient air at substantially lower levels than in an indoor environment. Although the concentrations of this bioaerosol greatly fluctuate with temperature, dew point, season and daytime, they do not represent increased health risks.
\end{abstract}

Key words: bioaerosol, airborne bacteria, fungi, endotoxins, seasonal variability, outdoor environment

Address for correspondence: V. Jirík, Department of Epidemiology and Public Health, Faculty of Medicine, University of Ostrava, Syllabova 19, 70300 Ostrava, Czech Republic. E-mail: vitezslav.jirik@osu.cz

http://dx.doi.org/10.21101/cejph.a4534

\section{INTRODUCTION}

Aerosol particles are of key importance for air pollution. On average, $24 \%$ of atmospheric aerosols are particles of biological origin referred to as bioaerosols $(1,2)$. These are various microorganisms (viruses, bacteria and fungi) as well as organic particles such as pollen grains, fungal spores and fragments, products or remnants of organisms $(3,4)$. Bioaerosol particles are of various sizes, ranging from pollen grains exceeding $100 \mu \mathrm{m}$ in aerodynamic diameter to viruses as small as several micrometers in size; that is, $\mathrm{PM}_{10}, \mathrm{PM}_{2.5}$ and $\mathrm{PM}_{1.0}$ particles are contained. Especially viruses, bacteria, spores and saccharides or proteins as components of the respirable fraction pose potential health risks $(3,5)$.

The main effect of bioaerosols on human health is the development of allergies and bronchial asthma caused by bacteria, fungi or pollen (5). Apart from bioaerosols, these conditions are contributed to by other airborne dust particles acting as carriers of allergens, aiding in spreading and maintaining bioaerosols in the atmosphere (6). Also important is the role of bioaerosols in the spread of infectious diseases $(5,7)$. Airborne endotoxins, lipopolysaccharide fragments of the cell of Gram-negative bacteria, produce acute toxic effects, bronchoconstriction, impaired lung function and, in case of chronic exposure, airway remodeling $(4,8)$. According to Thorne (9), the minimum dose of endotoxins needed to cause a respiratory disease is likely to be $10 \mathrm{EU} / \mathrm{m}^{3}$ (1 ng endotoxin may be approximately equal to 10 to $15 \mathrm{EU}$ - endotoxin units).

Bioaerosols are ubiquitous but their distribution and concentrations are affected by numerous factors such as the size, density and shape of particles, temperature and relative humidity of the air, sunshine and human activity on the Earth's surface. Several studies have shown that whereas air temperature and sunshine increase concentrations of bacteria and fungi, these decrease with rising relative humidity of the air $(6,10,11)$. Consistently with these regularities, significantly higher concentrations of bacteria and fungi were observed in many places of the world in summer and fall as compared with winter and spring (7). As for the variability throughout the day, a study by Fang et al. (11) reported the lowest concentrations of bacteria in the morning, as compared with the morning or evening. The concentrations of bacteria in the air generally range from 100 to $1,000 \mathrm{CFU} / \mathrm{m}^{3}$ (CFU - colony forming unit), with significant differences between places (5); for instance, the mean concentrations were 2,217 CFU $/ \mathrm{m}^{3}$ in Beijing (11) and $671 \mathrm{CFU} / \mathrm{m}^{3}$ in Poland neighbouring with our country (12). The acceptable indoor concentrations of bacteria or fungi are believed to be below $500 \mathrm{CFU} / \mathrm{m}^{3}$ (13); no acceptable or harmful outdoor concentrations have been defined yet.

This study is concerned with airborne outdoor aerosols in the suburb of the city of Ostrava in the course of one year. The 
objective was to obtain information on concentrations of bacteria, fungi and endotoxins posing a potential health risk. In this area, seasonal and daily distributions of bioaerosols in the air depending on temperature, humidity and dew point were measured. It was of particular interest to assess the relationship between bioaerosols and particulate matter as this highly industrial region is typically characterized by excessive dust concentrations.

\section{MATERIALS AND METHODS}

\section{Sampling Site}

Samples were collected in Polanka nad Odrou, which is suburban part of Ostrava city (Fig. 1). With its area of 17.3 square kilometers it is one of the largest city district inhabited by over 4,945 residents (1 October 2014). The river Odra flows along the border which is also the border of National nature reservation Polanská Niva. Part of this area is also incorporated into Protected Landscape Poodř́. This area is characterized by many of swamp forests, numerous ponds, streams (Polančice, Mlýnka) and gutters and there are also iodine-bromine water pumping stations that supply a nearby spa Klimkovice on Hýlov (14). This monitored locality was a separate village once and is characterized by agricultural production (cattle keeping, cereal grain growing and processing). Although the place itself is not directly affected by large industrial sources, the quality of air is similar to that in the entire region (particularly increased dustiness) (15).

\section{Geographical and Meteorological Conditions}

The Ostrava city and its district Polanka nad Odrou is located in south-western part of the Upper Silesian region in Upper Silesian Basin. The orientation profile of the Upper Silesian Basin from Jeseníky to Beskydy and location of monitored locality is shown in Figure 1. The average altitude in Ostrava reaches 227 meters above sea level, the annual average temperature is $8.6^{\circ} \mathrm{C}$ and the annual average precipitation reaches $568.3 \mathrm{~mm}$ (16). Prevailing wind direction is shown in wind rose presented in Figure 1.

\section{Sampling Methods}

The monitoring station was located according to the Directive 2008/50/EC of the European Parliament and of the Council (17) at open area in a residential area of Polanka nad Odrou near to local kindergarten. Monitoring was performed over one calendar year.

The device used for sampling bacteria and fungi was the RCS Plus air sampler (Biotest AG, Germany) with volume velocity approx. $50 \mathrm{l} / \mathrm{min}$, total air volume was $500 \mathrm{l}$ per 10 minutes. Microorganism samples were collected by active drawing of the air by centrifugal force onto medium-coated strips and routinely cultured (18). Agar strips TC (total count) - PET-foil coated with gel-like nutrient medium were used for bacteria. Agar Strips - RB (Rose-Bengal-Agar for Yeasts and Moulds) - plastic Air Sampler strips filled with medium were used for fungi. Two strips for determination of bacteria and fungi were collected 2 times for 10 minutes at 2 p.m. at 6-day intervals, totally 120 double samples. It has been shown that such interval between the measurements gives as reliable results as when the measurement is performed

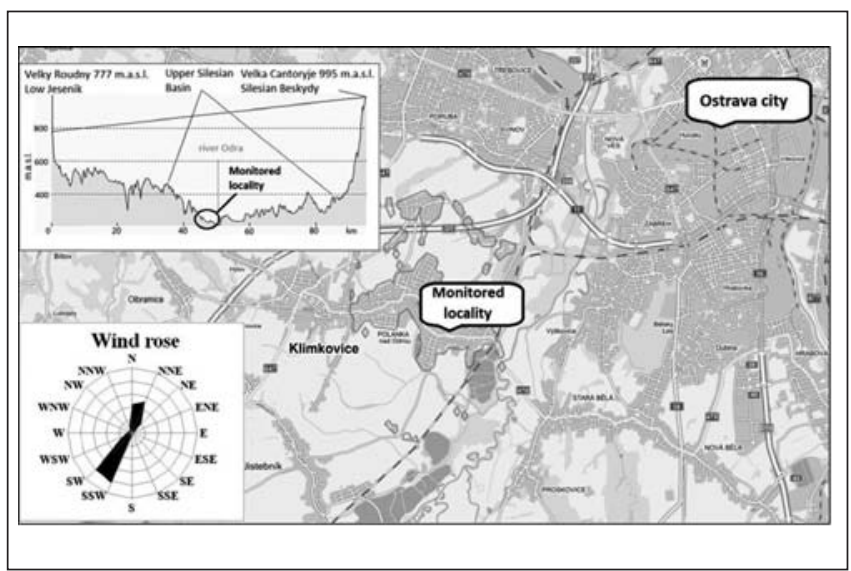

Fig. 1. Map of monitored locality with altitude profile and wind rose.

daily, in addition, such measurement is less demanding both physically and economically, and 6-day interval will ensure that it is during measurement captured evenly every weekday. To determine the daytime dependence, samples were collected repeatedly three times daily (8 a.m., 2 p.m. and 8 p.m.) every day over one week in winter and one week in summer (i.e. 2 strips per 2 times 10 minutes each at the specified time, 14 days, totally 42 double samples).

For sampling endotoxins IOM multidust sampler (SKC, USA) for inhalable dust was used. Total count of 59 dust samples were collected for 24 hours at 6-day intervals for sampling endotoxins employing $37 \mathrm{~mm} 0.45 \mu \mathrm{m}$ pore-size filters, volume velocity 2.7 1/min with total air volume $3.9 \mathrm{~m}^{3}$ per 24 hour. For endotoxin detection the semiquantitative gel-clot Limulus Amebocyte Lysate (LAL) assay was used (19).

Temperature, humidity and velocity were measured at the same time by calibrated electronic sensors with continuous computerized record, which were part of measuring station. Dew point $\mathrm{T}_{\mathrm{dp}}$ was calculated using formula with constants defined by the National Oceanic and Atmospheric Administration (NOAA). These valuations provide a maximum error of $0.1 \%$, for $30^{\circ} \mathrm{C}$ $\leq T \leq+35^{\circ} \mathrm{C} ; 1 \%<R H<100 \%$ (20).

$$
T_{d p}=\frac{243.5 \ln \left(\frac{R H}{100} \cdot e^{\frac{17.67 . T}{243.5+T}}\right)}{17.67-\ln \left(\frac{R H}{100} \cdot e^{\frac{17.67 \cdot T}{243.5+T}}\right)}\left[{ }^{\circ} \mathrm{C}\right]
$$

\section{Statistical Analysis}

Data obtained from the station were processed using the Stata 9 software (StataCorp, USA) and Excel spreadsheet software (Microsoft Corp, USA). As the data were found to be rather lognormally distributed, they were processed by the logarithmic transformation according to

$$
y^{\prime}=\log y \text {, }
$$

where y is an original dependent variable (e.g. bacteria concentration), $y^{\prime}$ is the variable after logarithmic transformation. The means and 95\% confidence intervals (95\% CI) of transformed data were recalculated by retransformation according to (21) $y^{\prime \prime}=10^{y^{\prime}+0.5 s_{y}^{2}}$,

where $y^{\prime \prime}$ is the corrected mean of variable after retransformation and $\mathrm{s}$ is standard deviation of $y^{\prime}$. 
Daily and seasonal variations in the presence of bacteria and fungi were determined using the ANOVA analysis of variance for a single factor and pairwise comparison. Exponential dependence of the occurrence of bacteria and fungi on temperature, humidity and dew point was observed. These associations have the following formula

$y=a \cdot e^{b \cdot x}$,

where $\mathrm{a}, \mathrm{b}$ are regression coefficients, $\mathrm{x}$ is independent variable (temperature, humidity, dew point).

\section{RESULTS}

In total 103 double samples for bacteria, 103 double samples for fungi and 59 samples for endotoxins were processed by statistical analysis (Table 1). The results of microorganisms measurements throughout the year are graphically depicted in Figure 2.

\section{Seasonal Variations}

Table 2 shows concentrations of bacteria and fungi in the air by season and pairwise comparisons between seasons. Concentrations of these microorganisms by season are also graphically depicted in Figure 3.

\section{Daytime Variations}

Table 3 shows concentrations of bacteria and fungi in the air by the daytime and pairwise comparisons between the times of the day in a season. Daytime distribution of concentrations is illustrated in Figure 4.

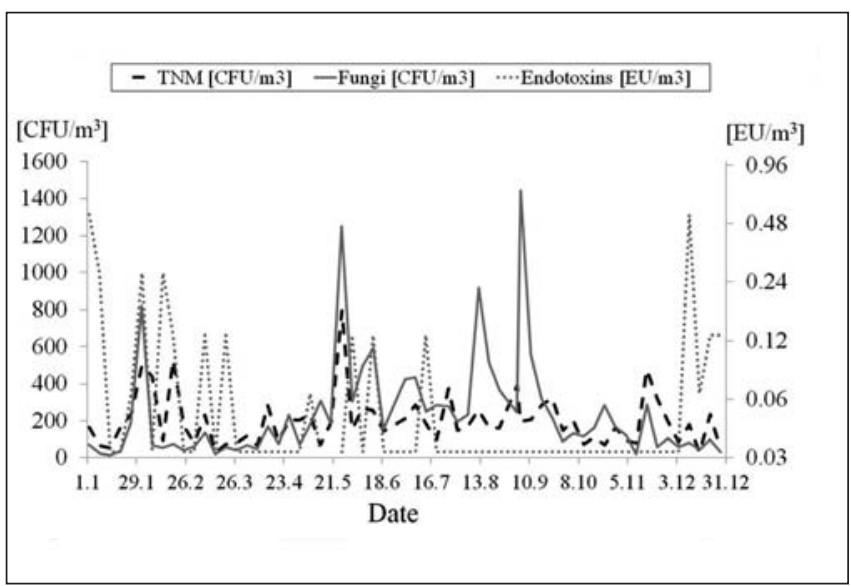

Fig. 2. The concentrations of bacteria, fungi and endotoxins throughout the year.

\section{Dependence on Temperature, Humidity and Dew Point}

To determine dependence of bacteria and fungi concentrations in the atmosphere on air temperature, humidity and dew point, regression analysis was performed (Table 4) and graphs of the relevant dependencies were constructed and presented in Figures 5, 6, 7.

\section{DISCUSSION}

The corrected mean (after retransformation) concentration of bacteria was $176 \mathrm{CFU} / \mathrm{m}^{3}$, that is below concentration levels reported by most of the studies performed in cities abroad as well as below the acceptable threshold for microbes in indoor environ-

Table 1. Basic statistical parameters for the concentrations of bacteria, fungi and endotoxins and measured parameters throughout the year

\begin{tabular}{|l|c|c|c|c|c|c|}
\hline & $\begin{array}{c}\text { Bacteria } \\
{\left[\mathrm{CFU} / \mathrm{m}^{3}\right]}\end{array}$ & $\begin{array}{c}\text { Fungi } \\
{\left[\mathrm{CFU} / \mathrm{m}^{3}\right]}\end{array}$ & $\begin{array}{c}\text { Endotoxins } \\
{\left[\mathrm{EU} / \mathrm{m}^{3}\right]}\end{array}$ & $\begin{array}{c}\text { Temperature } \\
{\left[{ }^{\circ} \mathrm{C}\right]}\end{array}$ & $\begin{array}{c}\text { Humidity } \\
{[\%]}\end{array}$ & $\begin{array}{c}\text { Wind velocity* } \\
{[\mathrm{m} / \mathbf{s}]}\end{array}$ \\
\hline $\mathrm{N}$ & 60 & 60 & 59 & 59 & 59 & 57 \\
\hline Mean & 199 & 239 & 0.076 & 11 & 73 & 1.3 \\
\hline CorrMean & 176 & 178 & 0.056 & - & - & - \\
\hline Median & 171 & 157 & 0.032 & 11 & 79 & 1.1 \\
\hline Minimum & 27 & 12 & 0.032 & -13 & 37 & 0.2 \\
\hline Maximum & 798 & 1,444 & 0.533 & 28 & 94 & 4.7 \\
\hline
\end{tabular}

$\mathrm{N}$ - count; Mean - arithmetic mean; CorrMean - after retransformation

*calm - wind velocity $\leq 0.2 \mathrm{~m} / \mathrm{s}$

Table 2. Concentrations of bacteria and fungi by seasons and pairwise comparisons

\begin{tabular}{|c|c|c|c|c|c|c|c|c|c|c|c|c|}
\hline \multirow[b]{2}{*}{ Season } & \multicolumn{4}{|c|}{ Bacteria [CFU/m $\left.{ }^{3}\right]$} & \multicolumn{4}{|c|}{ Fungi [CFU/m³] } & \multicolumn{4}{|c|}{ Pairwise comparison [p value] } \\
\hline & $\mathrm{N}$ & $95 \% \mathrm{Cl}_{\min }$ & $\begin{array}{l}\text { Corr- } \\
\text { Mean }\end{array}$ & $95 \% \mathrm{Cl}_{\max }$ & $\mathrm{N}$ & $95 \% \mathrm{Cl}_{\min }$ & $\begin{array}{l}\text { Corr- } \\
\text { Mean }\end{array}$ & $95 \% \mathrm{Cl}_{\max }$ & Spring & Summer & Fall & Winter \\
\hline Spring & 14 & 95 & 148 & 231 & 14 & 76 & 130 & 224 & - & $0.099^{1}$ & $0.230^{1}$ & $0.726^{1}$ \\
\hline Summer & 14 & 164 & 198 & 239 & 14 & 284 & 365 & 470 & $<0.001^{2}$ & - & $0.625^{1}$ & $0.240^{1}$ \\
\hline Fall & 16 & 141 & 191 & 258 & 16 & 129 & 209 & 340 & $0.192^{2}$ & $0.020^{2}$ & - & $0.439^{1}$ \\
\hline Winter & 15 & 107 & 168 & 264 & 15 & 46 & 75 & 123 & $0.172^{2}$ & $<0.001^{2}$ & $0.007^{2}$ & - \\
\hline
\end{tabular}




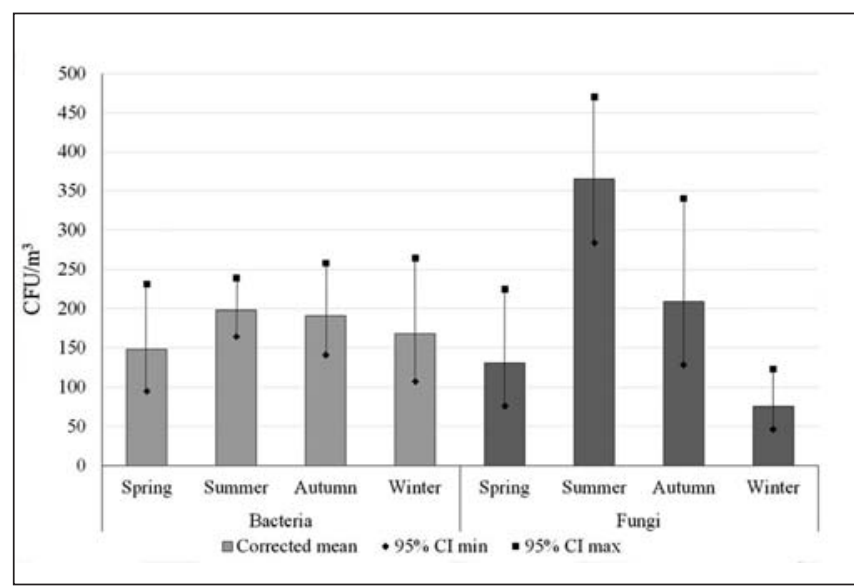

Fig. 3. Concentrations of bacteria and fungi by seasons.

ments. Similarly, with the corrected mean of $178 \mathrm{CFU} / \mathrm{m}^{3}$, fungi also had lower concentrations compared to other studies and the acceptable threshold $(5,22)$.

Although there were found higher concentrations of bacteria in samples collected during summer months, no significant seasonal changes were observed in concentrations of bacteria, contrary to concentrations of fungi. Significantly higher concentrations of fungi were noted in summer as compared with other seasons, in particular with spring and winter (Table 2 and Fig. 3). On the contrary, despite the small number of samples, statistically significant differences were revealed in the concentrations of bacteria during the daytime compared to non-significant differences in fungi (Table 3, Fig. 4).

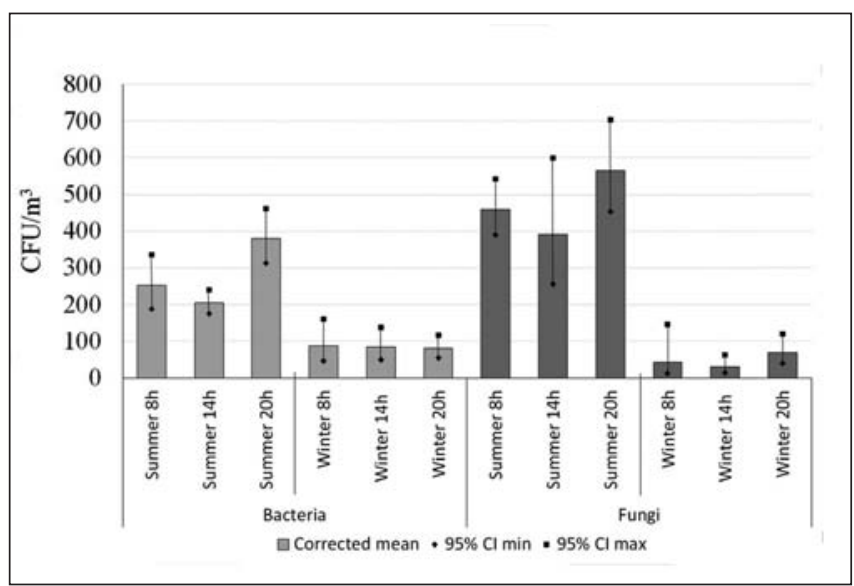

Fig. 4. Concentrations of bacteria and fungi during the day in summer and winter.

These findings are consistent with those in the Beijing study by Fang et al. (11) who reported the highest bacteria concentrations in the afternoon (in our study at evening), but only in summer. During winter, there were non-significant daily variations in concentrations of bacteria.

Similarly, concentrations of fungi were higher thought not significantly in the summer evenings than in other parts of the day. Higher concentrations of fungi were also observed in the winter evenings, however, again the differences were non-significant.

The non-significant differences in winter may be attributed to low temperatures and a lack of sunshine reducing the dynamics and generally decreasing atmospheric bioaerosol concentrations as well as to snow cover that "froze" many of the sources. Sum-

Table 3. Concentrations of bacteria and fungi distributed by daytime and pairwise comparisons

\begin{tabular}{|c|c|c|c|c|c|c|c|c|c|c|c|}
\hline \multirow{2}{*}{$\begin{array}{l}\text { Time of the } \\
\text { day }\end{array}$} & \multicolumn{4}{|c|}{ Bacteria $\left[\mathrm{CFU} / \mathrm{m}^{3}\right]$} & \multicolumn{4}{|c|}{ Fungi [CFU/m³] } & \multicolumn{3}{|c|}{ Pairwise comparison [p value] } \\
\hline & $\mathrm{N}$ & $95 \% \mathrm{Cl}_{\min }$ & $\begin{array}{l}\text { Corr- } \\
\text { Mean }\end{array}$ & $95 \% \mathrm{Cl}_{\max }$ & $\mathrm{N}$ & $95 \% \mathrm{Cl}_{\min }$ & $\begin{array}{l}\text { Corr- } \\
\text { Mean }\end{array}$ & $95 \% \mathrm{Cl}_{\max }$ & 8 a.m. & 2 p.m. & $8 p . m$ \\
\hline Summer 8 a.m. & 7 & 189 & 252 & 336 & 7 & 391 & 460 & 542 & - & $0.299^{1}$ & $0.031^{1}$ \\
\hline Summer 2 p.m. & 7 & 176 & 206 & 240 & 7 & 256 & 391 & 599 & $0.357^{2}$ & - & $<0.001^{1}$ \\
\hline Summer 8 p.m. & 7 & 314 & 380 & 461 & 7 & 454 & 565 & 703 & $0.183^{2}$ & $0.111^{2}$ & - \\
\hline Winter 8 a.m. & 7 & 47 & 87 & 161 & 7 & 13 & 44 & 147 & - & $0.980^{1}$ & $0.964^{1}$ \\
\hline Winter 2 p.m. & 7 & 51 & 84 & 138 & 7 & 14 & 30 & 64 & $0.945^{2}$ & - & $0.984^{1}$ \\
\hline Winter 8 p.m. & 7 & 56 & 81 & 117 & 7 & 41 & 70 & 120 & $0.195^{2}$ & $0.063^{2}$ & - \\
\hline
\end{tabular}

${ }^{1}$ bacteria, ${ }^{2}$ fungi

$\mathrm{N}$ - count; CorrMean - after retransformation; $95 \% \mathrm{Cl}_{\min / \max }-95 \%$ confidence interval $\mathrm{min} / \mathrm{max}$

Table 4. Regression analysis of the dependence of bacteria and fungi concentrations on temperature, humidity and dew point throughout the year

\begin{tabular}{|c|c|c|c|c|c|c|}
\hline & \multicolumn{2}{|c|}{ Temperature } & \multicolumn{2}{|c|}{ Humidity } & \multicolumn{2}{|c|}{ Dew point } \\
\hline & Bacteria & Fungi & Bacteria & Fungi & Bacteria & Fungi \\
\hline$N^{\prime}$ & 59 & 59 & 59 & 59 & 59 & 59 \\
\hline r (corr. coeff.) & 0.346 & 0.641 & 0.204 & 0.263 & 0.324 & 0.658 \\
\hline a (regr. coeff.) & 118.550 & 64.966 & 292.676 & 499.060 & 131.84 & 83.842 \\
\hline b (regr. coeff.) & 0.024 & 0.0723 & -0.00869 & -0.0174 & 0.0298 & 0.0939 \\
\hline$p(b)$ & $<0.001$ & $<0.001$ & 0.122 & 0.044 & 0.012 & $<0.001$ \\
\hline
\end{tabular}

$\mathrm{N}^{\prime}$ - number of paired data, $\mathrm{p}(\mathrm{b})$ - statistical significance for the regression coefficient $b$ 


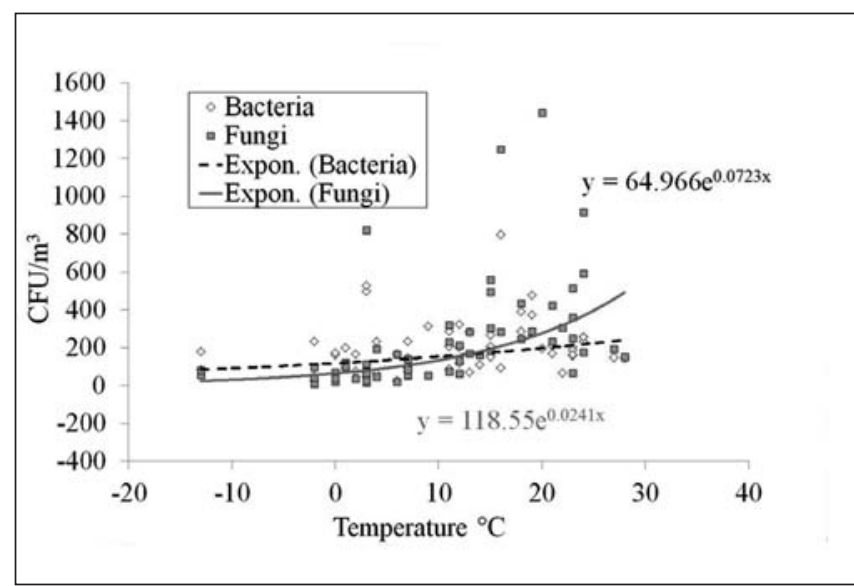

Fig. 5. Dependence of concentrations of bacteria and fungi in the air on temperatures $\left(y=a^{*} e^{b x}\right.$, with $x$ being temperature in ${ }^{\circ} \mathrm{C}$, $y$ being concentrations of bacteria or fungi, and $a$ and $b$ being regression coefficients).

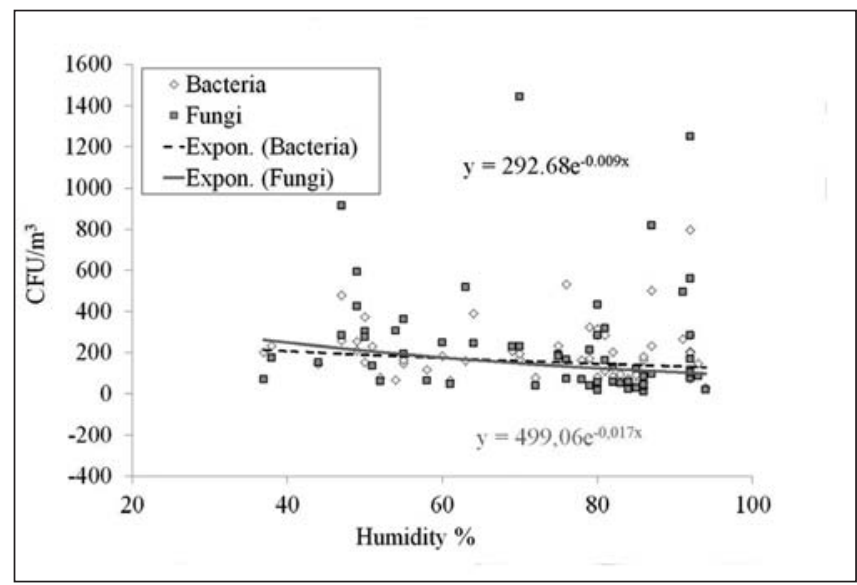

Fig. 6. Dependence of concentrations of bacteria and fungi in the air on humidity $\left(y=a^{*} e^{b x}\right.$, with $x$ being humidity in $\%, y$ being concentrations of bacteria or fungi, and $a$ and $b$ being regression coefficients).

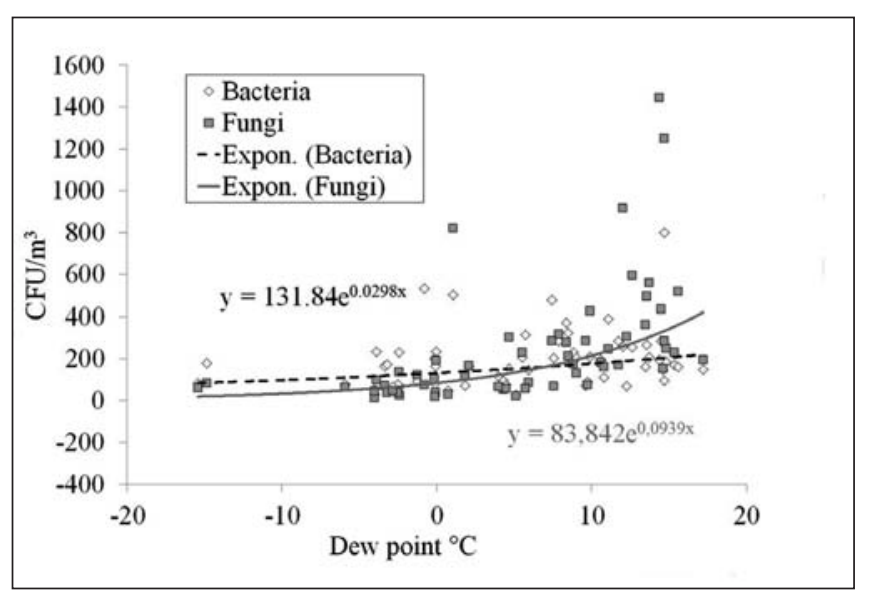

Fig. 7. Dependence of concentrations of bacteria and fungi in the air on dew point $\left(y=a^{*} e^{b x}\right.$, with $x$ being dew point in ${ }^{\circ} \mathrm{C}$, $y$ being concentrations of bacteria or fungi, and $a$ and $b$ being regression coefficients). mer, on the other hand, is favourable for the release of bacteria and fungi into the air and their maximum concentrations in the evening may be explained by certain accumulation during the day.

Concentrations of bacteria and fungi were found to be exponentially dependent on temperatures and dew points, with the stronger correlation for fungi than for bacteria. Relations to humidity were found very weak and apparently illogical, because with higher humidity the occurrences of microorganisms are a little lower. But from the results is clear that the humidity participates in the occurrence of bacteria and fungi together with the temperature, and it would be therefore better to express the association by a dew point, which reflects the temperature and humidity simultaneously (Table 4 and Figures 5, 6, 7).

As for endotoxins, most of the concentrations found reached relatively low levels, around the detection limit $\left(0.03 \mathrm{EU} / \mathrm{m}^{3} ; 43\right.$ samples from 59) and did not change significantly throughout the year. The corrected mean of endotoxin concentration using data, which was below the detection limit, was $0.056 \mathrm{EU} / \mathrm{m}^{3}$ (Table 1 and Figure 2). For example, indoor airborne endotoxin levels were measured in a 14-month study in 20 homes and ranged from 0.02 to $19.8 \mathrm{EU} / \mathrm{m}^{3}\left(0.002-1.98 \mathrm{ng} / \mathrm{m}^{3}\right)$ (23). Concentrations were highest in the spring and lowest in the winter and were not well correlated with endotoxin concentrations in settled dust. Similar air levels have been observed in Dutch homes (24). Woskie et al. reported an exposure of $1.9 \pm 6.4 \mathrm{EU} / \mathrm{m}^{3}\left(0.19 \mathrm{ng} / \mathrm{m}^{3}\right.$ geometric mean, SD $\left.0.64 \mathrm{ng} / \mathrm{m}^{3}\right)$ in office-workers $(\mathrm{n}=34)(25)$. Wan et al. reported a mean endotoxin concentration of $0.065 \mathrm{ng} / \mathrm{m}^{3}$ $\left(0.65 \mathrm{EU} / \mathrm{m}^{3}\right)$ in houses (26). It is obvious that higher endotoxin concentrations could be generally expected in an indoor than in outdoor environment. According to (25) exposure to airborne endotoxin levels more than $10-90 \mathrm{EU} / \mathrm{m}^{3}(9,27)$ for an extended period may result in significant damage to the respiratory system in general and the lungs in particular but such concentrations of endotoxin are not probable in an outdoor air. Although the occurrence of endotoxins should be accompanied by occurrence of gram-negative bacteria, in our study, such a correlation has not been confirmed.

\section{CONCLUSION}

The analysis of airborne bioaerosols in the suburbs of Ostrava showed lower concentrations of particles of biological origin than in other places throughout the world, despite the fact that this region is typically characterized by highly polluted air and frequently exceeded limit values for particulate matter.

The highest concentrations of fungi in the air were observed in summer as compared with the other parts of the year, for bacteria such results were, however, not significant. As far as daily variations are concerned, the highest concentrations were noted in the evenings, with the differences being non-significant for fungi and significant for bacteria. However, these findings of our study should be interpreted with caution, because they are obtained from a limited number of samples. Stronger dependence of fungi concentrations compared to bacterial ones on air temperatures and more on the dew points were proved during the whole year.

Endotoxins were found to be present in the air but the amounts were so negligible that no potential health effects could be anticipated. 


\section{REFERENCES}

1. Macher J, editor. Bioaerosols: assessment and control. Ohio: ACGIH; 1999.

2. Matthias-Maser S, Reichert K, Jaenicke R. Primary biological aeroso particles at the high alpine site of Jungfraujoch/Switzerland. J Aerosol Sci. 2000 Sep;31 Suppl 1:955-6.

3. Monks PS, Granier C, Fuzzi S, Stohl A, Williams ML, Akimoto H, et al. Atmospheric composition change - global and regional air quality. Atmos Environ. 2009 Oct;43(33):5268-350.

4. Kulkarni P, Baron PA, Willeke K. Aerosol measurement: principles, techniques, and applications. 3rd ed. Hoboken (NJ): John Wiley \& Sons; 2011.

5. Mamta, Shrivastava JN, Satsangi GP, Kumar R. Assessment of bioaerosol pollution over Indo-Gangetic plain. Environ Sci Pollut Res Int. 2015 Apr;22(8):6004-9.

6. Adhikari A, Reponen T, Grinshpun SA, Martuzevicius D, LeMasters G. Correlation of ambient inhalable bioaerosols with particulate matter and ozone: a two-year study. Environ Pollut. 2006 Mar;140(1):16-28.

7. Qi JH, Shao Q, Xu WB, Gao DM, Jin C. Seasonal distribution of bioaerosols in the coastal region of Qingdao. J Ocean U China. 2014 Feb;13(1):57-65.

8. Gilbert Y, Duchaine C. Bioaerosols in industrial environments: a review. Can J Civil Eng. 2009 Dec;36(12):1873-86.

9. Thorne PS, Reynolds SJ, Milton DK, Bloebaum PD, Zhang X, Whitten P, et al. Field evaluation of endotoxin air sampling assay methods. Am Ind Hyg Assoc J. 1997 Nov;58(11):792-9.

10. Jones AM, Harrison RM. The effects of meteorological factors on atmospheric bioaerosol concentrations - a review. Sci Total Environ. 2004 Jun 29;326(1-3):151-80.

11. Fang Z, Ouyang Z, Zheng H, Wang X, Hu L. Culturable airborne bacteria in outdoor environments in Beijing, China. Microb Ecol. 2007 Oct;54(3):487-96.

12. Pastuszka JS, Paw UKT, Lis DO, Wlazlo A, Ulfig K. Bacterial and fungal aerosol in indoor environment in Upper Silesia, Poland. Atmos Environ. 2000;34(22):3833-42.

13. EUR 14988. European Collaborative Action "Indoor air quality and its impact on man": biological particles in indoor environments. Report No.12. Luxembourg: Office for Official Publications of the European Communities; 1993.

14. Basic data about Polanka nad Odrou. Ostrava: Polanka nad Odrou [Internet]. Ostrava: Office city district Polanka nad Odrou, 2015 [cited 2016 Jun 14]. Available from: https://polanka.ostrava.cz/cs. (In Czech.)

15. Five-year average 2010 - 2014: PM10 annual average. Historical data quality of the air - OZKO [Internet]. Prague: Czech Hydrometeorological Institute; 2016 [cited 2016 Jun 17]. Available from: http://portal.chmi.cz/ files/portal/docs/uoco/isko/ozko/14petileti/png/PM10/14PM10_regT.gif. (In Czech.)
16. Statutory city of Ostrava - official webside: about Ostrava [Internet] Ostrava: Municipality of the city Ostrava; 2014 [cited 2015 Feb 1]. Available from: http://www.ostrava.cz/cs/o-meste.

17. Directive 2008/50/EC of the European Parliament and of the Council of 21 May 2008 on ambient air quality and cleaner air for Europe. Off J Eur Union. 2008 Jun 11;51(L152):1-44.

18. EN 13098: 2000. Workplace atmosphere. Guidelines for measurement of airborne microorganisms and endotoxin. Brussels: European Committee for Standardization; 2000.

19. EN 14031: 2003. Workplace atmosphere. Determination of airborne endotoxins. Brussels: European Committee for Standardization; 2003.

20. Relative Humidity and Dewpoint Temperature from Temperature and Wet Bulb Temperature [Internet]. El Paso (TX): National Oceanic and Atmospheric Administration, 2016 [cited 2016 Jun 14]. Available from: http://www.srh.noaa.gov/images/epz/wxcalc/rhTdFromWetBulb.pdf.

21. Meloun M. Statistical analysis of experimental data in chemometrics, biometrics, econometrics, and in other fields of natural sciences, engineering and social sciences. Prague: Plus; 1994. (In Czech.)

22. Qi JH, Shao Q, Xu WB, Gao DM, Jin C. Seasonal distribution of bioaerosols in the coastal region of Qingdao. J Ocean U China. 2014 Feb;13(1):57-65.

23. Park JH, Spiegelman DL, Burge HA, Gold DR, Chew GL, Milton DK. Longitudinal study of dust and airborne endotoxin in the home. Environ Health Perspect. 2000 Nov;108(11):1023-8.

24. Noss I, Wouters IM, Visser M, Heederik DJ, Thorne PS, Brunekreef B, et al. Evaluation of a low-cost electrostatic dust fall collector for indoor air endotoxin exposure assessment. Appl Environ Microbiol. 2008 Sep;74(18):5621-7.

25. Woskie SR, Virji MA, Kriebel D, Sama SR, Eberiel D, Milton DK, et al. Exposure assessment for a field investigation of the acute respiratory effects of metalworking fluids. I. Summary of findings. Am Ind Hyg Assoc J. 1996 Dec;57(12):1154-62.

26. Wan GH, Li CS. Indoor endotoxin and glucan in association with airway inflammation and systemic symptoms. Arch Environ Health. 1999 MayJun;54(3):172-9.

27. Dutch expert Committee on Occupational Safety a Committee of the Health Council of the Netherlands in cooperation with the Nordic Expert Group for Criteria Documentation of Health Risks from Chemicals. Endotoxins: health-based recommended occupational exposure limit. The Hague: Health Coucil of the Netherlands; 2010.

Received August 28, 2015 Accepted in revised form June 21, 2016 